\title{
The AllB's Second Annual Meeting: Cruising along without Much Disturbance
}

Dae Un Hong*

New York Correspondent

\section{Launching Jeju Initiative}

The Asian Infrastructure Investment Bank (“AIIB")'s second annual meeting was held on June 16-18, 2017 in South Korea's southern island of Jeju. It was the first time that the AIIB's annual meeting was held outside China. ${ }^{1}$ The meeting was attended by about 2,000 participants, including delegates from both 57 founding members and 20 new members along with different international organizations, academia, as well as businessmen, financiers, and journalists. The attendees included over 20 finance ministers of the 77 approved AIIB members, such as Australia, China, Georgia, India, Indonesia, and Laos. ${ }^{2}$ In its second annual meeting, the AIIB adopted resolutions accepting three new members-Tonga, Argentina, and Madagascar. Thus, its total approved membership has reached 80 , surpassing that of the Asian Development Bank ("ADB").

\section{The AllB and China's Influence}

The China-initiated AIIB was established in January 2016 to fund infrastructure projects in Asia. Many critics anticipated that the AIIB might serve China's interests, just as existing multilateral development banks ("MDBs") are serving the interests of some developed countries, especially the US. ${ }^{3}$ Indeed, at the first AIIB annual meeting in 2016 in Beijing, Chinese Vice Premier Zhang Gaoli said that "China hopes the AIIB can be actively involved in the development of countries

* JSD Candidate at Cornell Law School; Attorney-at-Law (Korea Bar). A.B.(Seoul Nat'l Univ.), J.D.(Hanyang Univ.), LL.M.(Northwestern). The author may be contacted at: dh632@cornell.edu 
along the Belt and Road Initiative," which is one of the core initiatives of the Xi Jinping regime. ${ }^{4}$

The AIIB, however, at least officially, has tried to distance itself from the Chinese government. ${ }^{5}$ China is the largest AIIB shareholder, with 27.5 percent of the voting rights, ${ }^{6}$ granting China veto power where special majority -two-thirds of the number of members representing three-quarters of the voting power - is required. ${ }^{7}$ China alone, however, cannot exercise its veto power in other matters, such as project approvals that require a simple majority. ${ }^{8}$

China's compromise has been evidenced by the fact that India, China's rival in Asia, has been accepted as the second most influential member by securing 7.9 percent of the voting rights. Actually, a project proposed by India was approved in July of this year despite the mounting tension over the border dispute between China and India (Table 1).

Table 1 Projects approved by the AllB (As of August 1, 2017)

\begin{tabular}{c|l|c|l|c|c}
\hline & \multicolumn{1}{|c|}{ Country } & $\begin{array}{c}\text { Financing } \\
\text { (USD million) }\end{array}$ & \multicolumn{1}{|c|}{ Sector } & Approval Date & Co-financing \\
\hline 1 & Tajikistan & 27.5 & Transport & June 24, 2016 & $\mathrm{O}$ \\
\hline 2 & Bangladesh & 165 & Energy & June 24, 2016 & \\
\hline 3 & Pakistan & 100 & Transport & June 24, 2016 & $\mathrm{O}$ \\
\hline 4 & Indonesia & 216.5 & Urban & June 24, 2016 & $\mathrm{O}$ \\
\hline 5 & Pakistan & 300 & Energy & Sept. 27, 2016 & $\mathrm{O}$ \\
\hline 6 & Myanmar & 20 & Energy & Sept. 27, 2016 & $\mathrm{O}$ \\
\hline 7 & Oman & 36 & Transport & Dec. 08, 2016 & \\
\hline 8 & Oman & 265 & Transport & Dec. 08, 2016 & \\
\hline 9 & Azerbaijan & 600 & Energy & Dec. 21, 2016 & $\mathrm{O}$ \\
\hline 10 & Indonesia & 100 & Urban & Mar. 22, 2017 & $\mathrm{O}$ \\
\hline 11 & Indonesia & 125 & Multi-sector & Mar. 22, 2017 & $\mathrm{O}$ \\
\hline 12 & Bangladesh & 60 & Energy & Mar. 22, 2017 & $\mathrm{O}$ \\
\hline 13 & India & 160 & Energy & May 02, 2017 & $\mathrm{O}$ \\
\hline 14 & Georgia & 114 & Transport & June 15, 2017 & $\mathrm{O}$ \\
\hline 15 & India & $150 *$ & Multi-sector & June 15, 2017 & $\mathrm{O}$ \\
\hline 16 & Tajikistan & 60 & Energy & June 15, 2017 & $\mathrm{O}$ \\
\hline 17 & India & 329 & Transport & July 04, 2017 & \\
\hline & Total & 2828 & & & \\
\hline
\end{tabular}

* Maximum amount 
The AIIB is also very willing to collaborate with the existing institutions. Thirteen out of seventeen approved projects are co-financed with other MDBs or institutions. In terms of amount, the total size of the syndicated loans has reached USD 2.03 billion, accounting for 71.9 percent of the total approved loans. ${ }^{11}$

Although critics have alleged that the AIIB would ignore international best practices, including global environmental standards, ${ }^{12}$ the AIIB has confirmed its support for renewable energy and sustainable infrastructure development. In his opening remarks at the AIIB's second annual meeting, AIIB President Jin Liqun stressed the Bank's role in facilitating the implementation of the Paris Agreement on climate change and in enforcing the 2030 Agenda for Sustainable Development. ${ }^{13}$ During the AIIB's second annual meeting, the Board of Directors approved its investment strategy in the energy sector that reflects international best practices. $^{14}$

\section{What Makes the AllB Attractive?}

Among sources of financial support for infrastructure provision in developing countries, MDBs have historically been among the most prominent. ${ }^{15}$ Although infrastructure has been widely accepted as a key factor in development, economic growth, and poverty reduction, ${ }^{16}$ the developed countries that controls existing MDBs have been less interested in infrastructure development in recent decades. ${ }^{17}$ MDB lending for infrastructure has also been declined quite considerably in relative terms. Over 70 percent of the operations of the World Bank's two main lending windows were directed to infrastructure projects in the 1950s and 1960s (and even more in earlier years), but it declined to a low of just 19 percent in 1999 before rebounding to the current level of 30-40 percent. $^{18}$

A recent ADB report estimated that Asia would need to invest USD 1.7 trillion per year in infrastructure until 2030 to maintain its growth momentum. Currently, the region's annual investments are estimated USD 881 billion in infrastructure. ${ }^{19}$ Existing MDBs have not been able to address this infrastructure investment gap. Moreover, as existing MDBs have been a key instrument of the US foreign policy, ${ }^{20}$ the AIIB is attractive to those countries that are seeking an alternative to the American initiative. In view of these countries, the AIIB is posing a challenge to the monopoly or cartel existing MDBs and is thus fostering competition. 


\section{Weakening Skepticism on the AllB}

Many have been skeptical of the future of the AIIB. One of the reasons for such skepticism is that the AIIB is not likely to raise enough funds for its investment. MDBs, such as the World Bank and ADB, are required to maintain a top-notch credit rating for successfully issuing bonds, which the AIIB did not obtain until recently. ${ }^{21}$ Soon after the second annual meeting of the AIIB, however, the three major credit rating agencies - Moody's Investors Service, Standard \& Poor's Global Ratings, and Fitch Group - all granted the AIIB their uppermost credit ratings. $^{22}$ Moody's noted that the AIIB's subscribed capital of USD 100 billion is already larger than those of more established Aaa-rated MDBs. ${ }^{23}$

The AIIB has been developing its objectives and guiding principles for its investment since its establishment. Its first product is the abovementioned investment strategy in the energy sector. Since the AIIB has clear strategies in other areas of infrastructure, such as transportation and urban development, the transparency and predictability of its investment will be further enhanced.

In addition, as noted above, most projects that the AIIB has approved so far have also been co-financed by other MDBs, such as the World Bank and the ADB. Collaboration with other MDBs will help the AIIB to learn from them (e.g., project management and post-evaluation skills), ${ }^{24}$ thereby building its capacity and reducing the risk of failure in its projects.

\section{REFERENCES}

1. Qiang Hou, Hosting AIIB's 2nd annual meeting to have great meaning for S. Korea: officials, Xinhuanet, May 30, 2017, available at http://news.xinhuanet.com/english/2017-05/30/ c_136325745.htm (last visited on Aug. 1, 2017).

2. See AIIB annual meeting closes with 3 new members, Yonhap News, June 18, 2017, available at $\mathrm{http}: / /$ english.yonhapnews.co.kr/national/2017/06/18/0301000000AEN2017061 8002400320.html (last visited on Aug. 1, 2017).

3. S. Morris, Responding to AIIB: U.S. Leadership at the Multilateral Development Banks in a New Era, Council on Foreign Relations, Sept. 2016, at 2, available at https://www.cfr.org/ sites/default/files/pdf/2016/08/Discussion_Paper_Morris_AIIB_OR.pdf (last visited on Aug. 1, 2017). 
4. See Opening ceremony of AIIB annual meeting held in Beijing, CCTV, June 25, 2016, available at http://english.cctv.com/2016/06/25/VIDE4VVO2i0v2ReUu46zfrXM160625. shtml (last visited on Aug. 1, 2017).

5. Kenichi Yamada \& Issaku Harada, The AIIB adds members and distances itself from Beijing: Chinese-led bank continues to play it safe with syndicated loans in second year, NiKKEI Asian Rev., June 22, 2017, available at https://asia.nikkei.com/magazine/20170622/PoliticsEconomy/The-AIIB-adds-members-and-distances-itself-from-Beijing (last visited on Aug. 1, 2017).

6. AIIB, Members and prospective members of the bank, June 17, 2017, available at https:// www.aiib.org/en/about-aiib/governance/members-of-bank (last visited on Aug. 1, 2017).

7. Jing Fu, AIIB chief rules out China veto power, China DAILY, Jan. 27, 2016, available at http://www.chinadaily.com.cn/business/2016-01/27/content_23265846.htm (last visited on Aug. 1, 2017).

8. Id.

9. India has been very active regarding AIIB. Six out of the twelve projects now being reviewed by AIIB were proposed by India. See AIIB, Proposed projects, available at https://www.aiib. org/en/projects/proposed (last visited on Aug. 1, 2017).

10. The energy sector has the most investments, with seven approved projects (USD1.37 billion). The transport sector follows with six projects (USD 871.5 million). Other than the projects in these two sectors, two urban development projects (USD 316.5 million) and two multi-sectoral projects (USD275 million) were approved. See AIIB, Approved projects, available at https://www.aiib.org/en/projects/approved (last visited on Aug. 1, 2017).

11. Supra note 9.

12. S. Dasgupta, AIIB takes big strides amid fears about China's dominance, VOA News, June 27, 2016, available at https://www.voanews.com/a/aiib-big-strides-fears-chinadominance/3394153.html (last visited on Aug. 1, 2017).

13. S. Jungcurt, AIIB to step up support for renewable energy, sustainable infrastructure development, IISD SDG KNOWLEDGe HuB, June 20, 2017, available at http://sdg.iisd.org/ news/aiib-to-step-up-support-for-renewable-energy-sustainable-infrastructure-development (last visited on Aug. 1, 2017).

14. AIIB, Energy sector strategy: sustainable energy for Asia, June 15, 2017, available at https:// www.aiib.org/en/policies-strategies/strategies/.content/index/_download/aiib-energy-sectorStrategy-2017.pdf (last visited on Aug. 1, 2017).

15. C. Humphrey, Infrastructure finance in the developing world: challenges and opportunities for multilateral development banks in 21st century infrastructure finance, G-24 and GGGI Working Paper Series, June 2015, at 1, available at https://www.g24.org/wp-content/ uploads/2016/05/MARGGK-WP08.pdf (last visited on Aug. 1, 2017).

16. Id.

17. E.g., the World Bank has prioritized rule of law programs in developing countries, which 
has significantly increased its grants for such projects since the 1980s. See S. Humphreys, Theatre of the Rule of Law Transnational Legal Intervention in Theory and Practice 1312 (2012), available at http://codolc.com/files/04/1a/041a1 ca0bf6dde72a82491e0ead66805.pdf; World Bank, About the World Bank in Justice Reform, available at http://web.worldbank.org/ WBSITE/EXTERNAL/TOPICS/EXTLAWJUSTINST/0,,contentMDK:23138640 menuPK:1 974078 pagePK:210058 piPK:210062 theSitePK:1974062,00.html (all last visited on Aug. 1, 2017).

18. Humphrey, supra note 15 , at 3.

19. ADB, MeEting Asia's Infrastructure Needs xi (2017), available at https://www.adb.org/sites/ default/files/publication/227496/special-report-infrastructure.pdf (last visited on Aug. 1, 2017).

20. Morris, supra note 3 , at 2.

21. In addition, the AIIB does not have a domestic credit rating in China yet. See N. Trentmann, China-led infrastructure bank secures AAA rating from Fitch, WALL Sт. J., July 14, 2017, available at https://www.wsj.com/articles/china-led-infrastructure-bank-secures-aaa-ratingfrom-fitch-1500054398 (last visited on Aug. 1, 2017). The AIIB may have less incentive to do so because, unlike the size of stock markets in China, the size of the bond market in China is relatively small in comparison to that of its counterparts in the US and the EU.

22. Dongmiao Zhang, Economic watch: AIIB completes hat trick of global AAA ratings, XINHUANET, July 19, 2017, available at http://news.xinhuanet.com/english/2017-07/19/c_136456409.htm (last visited on Aug. 1, 2017).

23. Moody's Investors Service, Moody's assigns first-time Aaa issuer rating to Asian Infrastructure Investment Bank; outlook stable, Global Credit Research, June 29, 2017, available at https://www.moodys.com/research/Moodys-assigns-first-time-Aaa-issuer-rating-to-AsianInfrastructure--PR_368348 (last visited on Aug. 1, 2017).

24. J. Wilson, What does China want from the Asian Infrastructure Investment Bank?, Australian Outlook, July 3, 2017, available at http://www.internationalaffairs.org.au/ao-blog-post/whatdoes-china-want-from-the-aiib (last visited on Aug. 1, 2017). 